\title{
一种新的基于拓扑结构特征的微裂隙-孔隙空间 描述方法
}

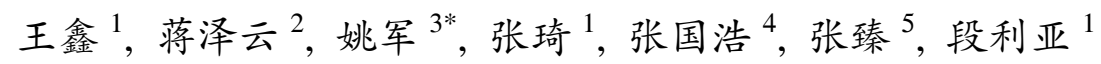

1. 齐鲁工业大学(山东省科学院), 山东省科学院海洋仪器仪表研究所, 青岛 266000;

2. Institute of Petroleum Engineering in Heriot-Watt University, Edinburgh UK EH14 4AS, Scotland;

3. 中国石油大学(华东)石油工程学院, 青岛 266580;

4. 中海石油(中国)有限公司天津分公司, 天津 300459;

5. 亚信科技中国研发中心, 北京 100000

* 联系人, E-mail: yaojunhdpu@126.com

2017-03-20 收稿, 2017-07-12 修回, 2017-07-12 接受, 2017-09-06 网络版发表

国家自然科学基金(51504146，51234007，51490654)、高等学校学科创新引智计划(B08028)和山东省科学院青年基金 (2015QN016, 2014QN030)资助

摘要微裂隙在多孔介质储层大量发育并与基质孔隙连通, 是流体渗流特别是非常规储层油气渗流的重要通 道. 高精度无损成像技术以及数字岩心技术的快速发展, 为孔裂隙空间描述、孔裂隙模型构建等研究提供了数据 支撑. 本文基于传统孔隙空间拓扑学，分析裂隙拓扑结构特征，充分考虑三维裂隙空间区别于普通孔隙的面状特 征以及与基质孔隙之间的相互连通关系，提出“特征点化”的思路，将裂隙空间点进行分类，形成了适用于多种孔 裂隙空间的描述以及结构特征分析方法. 首先基于传统孔隙拓扑结构分析方法，提出“线面共存”的新骨架模型， 提取裂隙中轴骨架面、中轴骨架线, 精细刻画裂隙轮廓以及孔裂隙连通关系; 其次, 基于各类空间点的拓扑结构 共性分别提取相应点集，分割孔隙、裂隙空间，构建微裂隙-孔隙骨架模型；第三，基于新的孔裂隙骨架模型提取 孔裂隙空间的几何-拓扑结构特征参数, 获取裂隙孔隙度、开度、倾角等重要裂隙几何参数, 以及孔裂隙配位数、 裂隙发育范围等拓扑参数; 最后基于上述骨架提取描述方法, 对理想与真实孔裂隙空间的数字岩心进行了骨架提 取和分析. 从微裂隙拓扑形态开展研究进而对裂隙-孔隙空间描述, 可简化此类孔隙介质的建模过程, 为后续气、 液流动模拟提供准确数据基础, 促进缝洞介质油气开发的进展.

关键词数字岩心, 微裂缝, 孔隙空间骨架模型, 裂缝结构建模, 空间拓扑结构

全球油气藏, 特别是非常规油气储层中广泛发 育具有良好导流能力的微裂隙结构 ${ }^{[1]}$. 探寻其中的流 体运移机理, 对于优化宏观裂缝性油藏数值模拟具 有十分重要的实际应用价值 ${ }^{[2]}$. 目前常用的孔隙级流 动模拟方法如格子玻尔兹曼方法 $(\mathrm{LBM})^{[3,4]}$ 以及水平 集方法 ${ }^{[5]}$, 直接对微裂隙空间开展模拟, 结果较为精 确, 但会带来巨大计算量; 若将裂隙模型等价为传统
平板模型或规则网络模型 ${ }^{[6 \sim 8]}$, 计算速度会提升, 但 由于过于弱化裂隙结构特征会带来显著的计算误 差 ${ }^{[9]}$. 因此, 如何准确识别裂隙构建微裂隙骨架模 型, 进而提取微裂隙的拓扑、几何结构特征等工作受 到科研工作者的持续关注.

飞速发展的高精度成像技术作为一种新的研究 手段, 可以将岩心孔隙空间转化为数字图像, 开启了

引用格式: 王坴金, 蒋泽云, 姚军, 等. 一种新的基于拓扑结构特征的微裂隙-孔隙空间描述方法. 科学通报, 2018, 63: 579-589 Wang X, Jiang Z Y, Yao J, et al. Extraction and identification methods of micro-fractured characteristics information in pore space of porous media based on morphological theory (in Chinese). Chin Sci Bull, 2018, 63: 579-589, doi: 10.1360/N972017-00311 
孔隙级多孔介质建模的数字岩心时代 ${ }^{[10]}$. 获得岩心 孔隙结构扫描数据后, 可以通过一些通用的图像处 理软件人工简单测量孔裂隙的一些结构参数, 但无 法做到批量处理岩心数据 ${ }^{[11]}$. 近年来, 一种结合形 态学操作与数字岩心的方法逐步应用在孔隙空间结 构表征研究中, 这种方法具有拓扑结构不变性, 可以 准确描述孔隙空间结构. 针对普通孔隙空间, Lee等 人 $^{[12]}$ 提出了中轴线理论来表征孔隙空间的拓扑几何 结构特征并得到配位数、孔隙半径等重要参数. 基于 几何拓扑学理论, Lindquist等人 ${ }^{[13,14]}$ 又进一步发展出 孔隙空间收缩算法, 通过剔除对孔隙结构特征无意 义的简单点, 构建孔隙空间的中轴骨架模型. 在此基 础上, 各类骨架提取优化算法层出不穷 ${ }^{[15 ~ 19]}$. 同时, 也催生出了包含孔隙结构信息和孔隙连通关系的孔 隙网络模型, 进一步推动孔隙尺度流动模拟的发 展 $^{[20 ~ 24]}$.

微裂隙是造成孔隙空间非均质、多尺度的主要原 因之一, 但目前基于裂缝真实延展和发育形态角度 开展的研究较少. 分形描述裂缝对裂缝网络的描述 虽然有效, 但无法适用于非网络形态的单条裂 缝 ${ }^{[25,26]}$. 基于孔隙形态学研究的积累, 骨架化模型经 过实践检验具有较多优势; 不仅可以更直观地展现 复杂三维孔隙空间的拓扑结构, 而且可以在不改变 孔隙空间拓扑特征的前提下简化孔隙结构描述, 同 时保留孔隙空间的几何性质, 例如空间的几何中心 等. 因此, 在充分考虑到微裂缝与孔隙的结构差异前 提下, 骨架化模型可以用于对裂隙的真实形态进行 描述. 传统中轴线骨架化模型以线性模型描述优势 流动路径, 对于较为复杂的孔隙空间结构, 不足以保 持其拓扑结构, 容易造成后期结构分析以及出现流 动模拟的较大误差 ${ }^{[27]}$. Jiang 等人 ${ }^{[28,29]}$ 提出面状骨架, 对更好描述孔隙空间中的扁平、平板结构作了进一步 尝试. 本文将微裂隙看做孔隙空间中的特殊孔隙, 在 总结微裂隙与普通微孔隙拓扑结构不同的基础上, 提出了结合形态学操作理论的新的孔裂隙空间骨架 提取算法, 可以识别微裂隙, 构建含裂隙结构的骨架 模型, 提取微裂隙结构特征如开度、倾角、连通性等.

\section{1 岩石中的微裂隙结构}

肉眼无法观测到的裂隙称为微裂隙, 指岩石中 由于应力、断层、褶皱等造成的不连续面, 常发育在 粒间、晶间、晶内, 有开放式、闭合式和充填式 3 种
方式 ${ }^{[30]}$. 其中开放式以及充填式的微裂隙是微裂隙 流动模拟的主要研究对象. 岩心中发育数量多、分布 广、形状不规则的中、小型微裂隙与基质孔洞共同构 成多尺度的储层流体渗流网络, 特别是非常规储层 岩石中, 由于孔隙欠发育且连通性差, 而大量发育且 连通性较好的微裂隙则成为油气渗流的主要通道这 使得含微裂隙的孔隙空间表征, 特别是微裂隙与基 质微孔隙之间的连通关系受到广泛关注, 成为热点 研究领域.

岩石成像技术的快速发展, 让微裂隙三维结构 形态可以清晰展现在数字图像中(图1). 与常规孔隙 的管状结构不同，微裂隙空间结构则表现出更为复 杂的面状和多尺度特征: (1) 微裂隙空间的断层几何 形状成楔状分布，并向发育方向不断延伸; (2) 几何 尺寸相比, 与之相连的微孔大出几个数量级; (3) 微 裂隙与微孔隙彼此交错延展, 在微裂隙周围又布满 许多与之连通的微孔隙网络.

含微裂隙的骨架模型要具备拓扑结构特征不变 性，不仅要保证流体在孔隙空间的管状流动路径以 及裂隙中的面状流动路径, 更要真实描述孔裂隙之 间的害流现象. 因此，不同于普通孔隙空间骨架可以 被描述成线状组合的网络结构, 含微裂隙的骨架模 型结构应做到“线面共存”。骨架线(中轴线)描述微孔 隙空间中的线状流动路径, 骨架面(中轴面)描述微裂 隙的面状特征. 与普通孔隙空间的线状骨架类似, 裂 隙中轴面应位于整个微裂缝的中轴位置, 保持空间 流体流动的特性(即拓扑结构不改变), 并且厚度也应 为一个体素的连续面状结构. “线、面”相互连通表征 微裂隙之间、微裂隙与基质微孔隙之间等的复杂的多 尺度连通关系。

\section{2 裂隙-孔隙空间描述方法}

\section{1 “点”化裂隙-孔隙空间}

随着 $\mathrm{CT}$ 、聚焦离子束扫描电子显微镜等图像采 集技术的发展，获取孔裂隙空间的数字三维图像越 来越方便快捷. 基于几何拓扑学理论将二值化数字 岩心图像与孔隙空间联系起来(图2), 以“点”作为组 成空间的基本元素来对孔裂隙空间进行描述，利用 不受分辨率所影响的微裂隙拓扑形态共性开展研究, 将空间维度、图像、邻居域等概念有机结合起来，可 以更好地阐释孔裂隙空间“线、面共存”的拓扑特征, 

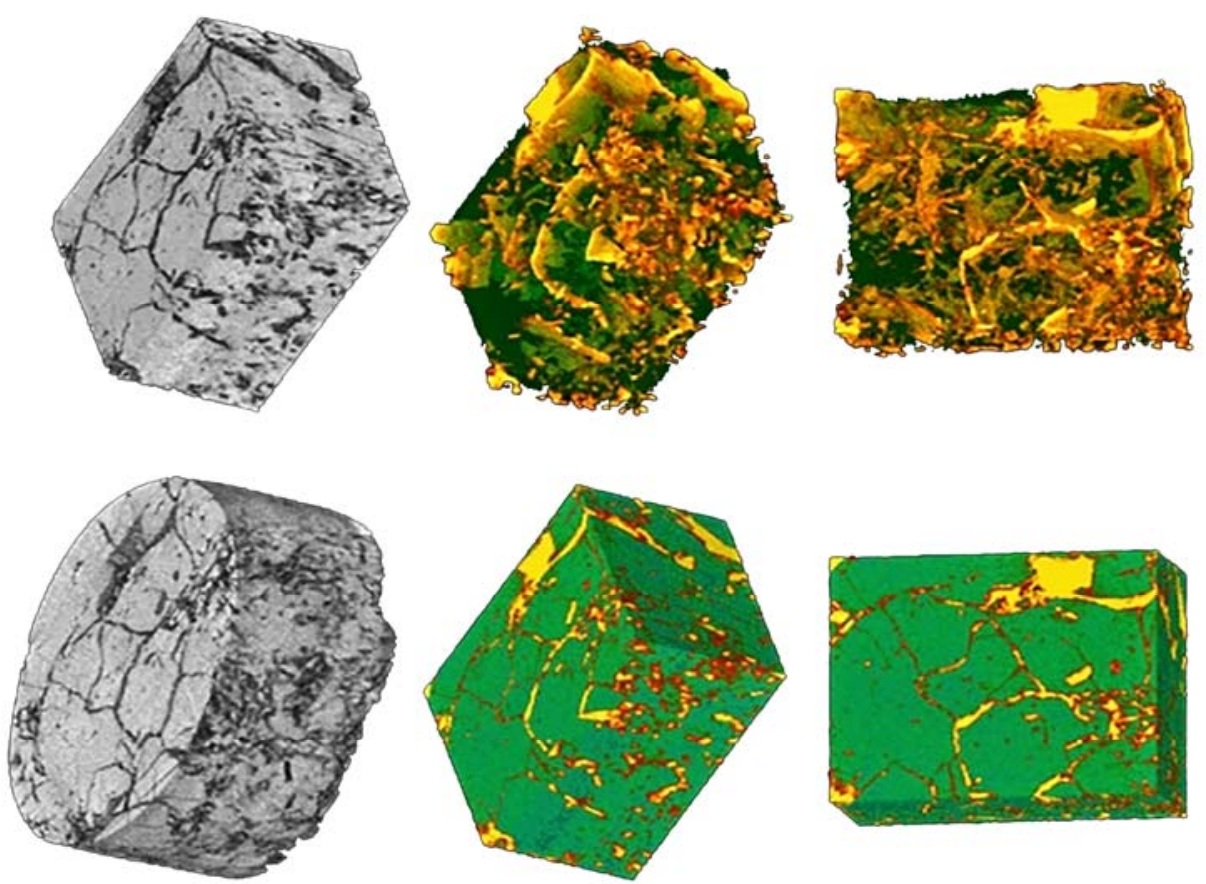

图 1 (网络版彩色)岩石中的微裂缝热成像

Figure 1 (Color online) Thermal images of micro-fracture in rocks

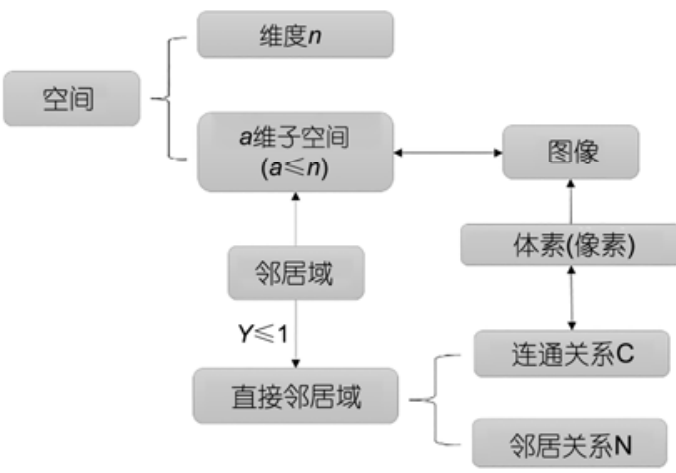

图 2 空间与图像之间的关系

Figure 2 Relationship between image and space

进而表征微裂隙空间真实形态. 因此, 从微裂隙孔隙 空间的拓扑结构特征出发对骨架面、骨架线进行描 述, “点”化裂隙空间, 定义裂隙孔隙空间点为简单 点、中轴线点、中轴面点、中轴边缘点(图3). 其中, 简 单点为删除后不会对原始孔隙空间的拓扑结构产生 影响的体素点 ${ }^{[31]}$; 中轴线点、中轴面点、中轴边缘点 共同组成裂隙孔隙空间骨架模型, 中轴线点集表征 孔隙管状特征, 组成骨架线; 中轴面点集与中轴边缘 点集组成骨架面, 其中面点表征裂隙的面状特征, 边 缘点表征孔缝边界, 以确定裂缝发育范围及裂隙与 周围基质孔隙的连通关系.

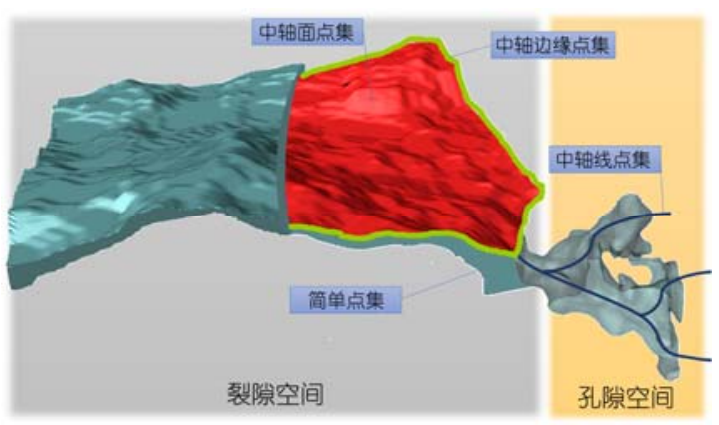

图 3 (网络版彩色)“点”化裂缝空间概念图

Figure 3 (Color online) Conception of digital point sets of the microfractured space

\section{2 简单点与中轴线点}

中轴线点组成普通孔隙空间连续的、单体素宽度 的骨架线模型. 目前应用广泛的孔隙空间提取方法 主要是Lindquist等人 ${ }^{[13,32]}$ 首先商业化的简单点消除 算法，通过由孔隙空间边缘向内部的遍历，不断识别 孔隙空间中的简单点并进行删除从而得到孔隙空间 中轴线骨架. 这种算法实际是将量化后的拓扑结构 权重参数映射到直接空间邻居域中来实现 ${ }^{[33 ~ 36]}$.

(1) 空间邻居域. 二值化孔隙空间数字岩心图 像，即以正方体形状的体素为基本构成元素的集合， 这些体素被赋予数值 0 或 1 . 基于Kong 与Rosenfeld ${ }^{[37]}$ 
的理论, 三维的二值图像I被定义为一个四维数组 $I=(V, a, b, B)$, 其中 $V$ 代表待研究空间; $B$ 代表 $V$ 的一个 子空间, 通常以 $B$ 表示目标空间即孔隙空间, 而用 $V / B$ 表示背景空间即固体颗粒空间; $a, b$ 分别代表目标 空间与背景空间的连接关系, 连接方式有 3 种: 点连 接即26连通、边连接即18连通、面连接即6连通. 空 间中某一体素与其他体素之间存在连接或非连接的 关系, 即直接邻居域的定义. 与孔隙空间中的一点 $\mathrm{p}$ 存在点连接关系的 26 个点, 即 $\mathrm{p}$ 点的 26 个直接邻居点, 组成的 $3 \times 3 \times 3$ 的最小空间就称点 $\mathrm{p}$ 的直接邻居域. 通 过量化直接邻居域的拓扑结构特征可以表征三维空 间的整体形态.

（2）拓扑结构权重参数. 直接邻居域中有两个 重要的权重参数: $T_{6}$ 和 $T_{26}$. $T_{26}$ 即去除 $\mathrm{p}$ 点的 26 邻居域 $N_{26}{ }^{*}(\mathrm{p})$ 中目标点集合的个数. $T_{6}$ 则表示去除 $\mathrm{p}$ 点的 18 邻居域 $N_{18}{ }^{*}(\mathrm{p})$ 中与点 $\mathrm{p}$ 存在 6 连通关系背景点的集合 个数, 注意每一个与 $p$ 点存在 6 连通关系的背景点集 合都满足: (i ) 其中每个体素与 $\mathrm{p}$ 的连通应满足 18 连 通 $C_{18}(\mathrm{p})$; ( ii ) 至少有一个体素与 $\mathrm{p}$ 应该是 6 连通 $C_{6}(\mathrm{p})$. 按照以上定义, 图4(a)去除p点的26邻居域中, 共有 3 个目标点集合: $\left[r_{1}, r_{2}, r_{3}\right],\left[q_{1}, q_{2}\right],[o]$, 即 $\mathrm{p}$ 点的 $T_{26}=3$; 图4(b)去除p点的 18 邻居域中, 共有一个与 $\mathrm{p}$ 点 存在6连通关系的背景点集合: $\left[q_{2}, q_{3}\right]$, 即 $\mathrm{p}$ 点的 $T_{6}=1$.

简单点的直接邻居空间中的背景与目标空间的 拓扑结构权重参数相等并且其值均为 1 , 即 $T_{6}(\mathrm{p})=$ $T_{26}(\mathrm{p})=1^{[38]}$. 普通孔隙空间中的简单点全部被消除 后, 就得到了孔隙空间的骨架线点集合, 进而可以构 建与原图像中的孔隙空间拓扑结构一致的孔隙空间 骨架模型 ${ }^{[39,40]}$.

\section{3 中轴面点}

传统中轴面提取方法主要有最大内切球方法、烧 草法以及缩减算法 ${ }^{[41]}$. 使用最大内切球方法提取微 裂隙骨架时会出现断层, 导致中轴面不连续; 使用烧 草法提取的中轴面是连续的, 但是中轴面上会出现 对流动不产生贡献的面(4个边角面), 无法保证微裂 隙与基质骨架之间的空间流体流动特性; 缩减算法 在骨架提取过程中会受到裂隙发育方向的影响, 并 且计算量巨大. 总之, 在无约束条件下中轴面的准确 定位比较困难. 不同于基于简单邻居关系的传统中 轴面描述算法 ${ }^{[42 ~ 44]}$, 本文基于拓扑结构权重参数并 结合直接空间邻居域理论, 将中轴面定义为中轴面

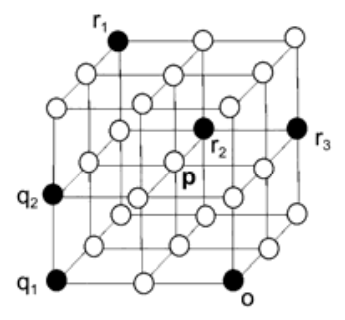

(a)

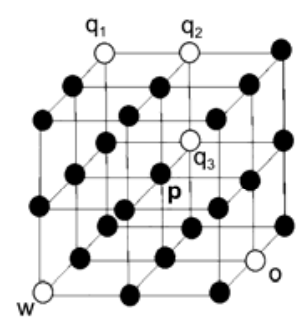

(b)
图 4 点p的直接邻居域空间. (a) $T_{26}=3$; (b) $T_{6}=1$, 其中黑色为目标点, 白色为背景点

Figure 4 The 26 neighbors of point p. (a) $T_{26}=3$; (b) $T_{6}=1$, black: object points; white: background points

点与中轴边缘点的集合.

中轴面点即位于微裂隙骨架面上, 表征微裂隙 面状特征的体素点. 中轴面点的集合构成微裂隙空 间中心的二维平面. 通过引人表征简单点拓扑特征 的拓扑结构权重参数 $T_{6}, T_{26}$, 中轴面点点集可表示为 $T_{6}>1$ 的全部体素点. 论证如下, 假设中轴骨架面已经 提取完毕(图5), 中心处为中轴骨架面, 其余部分为 除骨架外的其他空间. 取其中某一中轴面点 $\mathrm{p}$ 的 $3 \times 3 \times 3$ 直接邻居域量化面点特征, 该邻居域中存在一块以面 点 $\mathrm{p}$ 为中心的中轴面局部, 且以该局部中轴面为界将 整个邻居域空间分为两个部分. 引人Hadwiger ${ }^{[45]}$ 提出 的基于贝蒂数(Betti number)的欧拉演化方程对面点 直接邻居域进行描述

$$
N_{n}(V)=\sum_{i=0}^{n-1}(-1)^{i} H_{i}(V),
$$

其中, 在三维孔裂隙空间中以 $H_{0}(V)$ 代表连接体个数. 反推可知, 此模板中固体颗粒空间的 $H_{0}(V)$ 一定大于 1 , 任何其他情况都会导致 $\mathrm{p}$ 点位面点的前提不成立. 如 $H_{0}(V)=1$, 中轴面被击穿, $\mathrm{p}$ 点转换为边缘点; $H_{0}(V)$ $<1$, 则 $\mathrm{p}$ 点被完全包裹, 确定 $\mathrm{p}$ 点为面点或简单点, 仍 需进一步处理. 在该 $3 \times 3 \times 3$ 单位模版中, 固体颗粒空 间的 $H_{0}(V)$ 可映射为 $\mathrm{p}$ 点的拓扑结构权重参数 $T_{6}$, 因此 可定义中轴面点为 $T_{6}>1$ 的全部体素点. 通过判断所 有孔隙空间点的拓扑参数 $T_{6}$, 获得表征微裂隙面状 特征的中轴面点集合.

\section{4 中轴边缘点}

相对于微裂隙空间的面状、大尺度特征, 与之相 连的微孔隙呈线状、小尺度、簇状分布的特征，基于 孔、裂隙之间的尺度差异提取上述中轴面点、中轴线 点后，微孔隙空间与微裂隙空间就被分割开来. 边界 


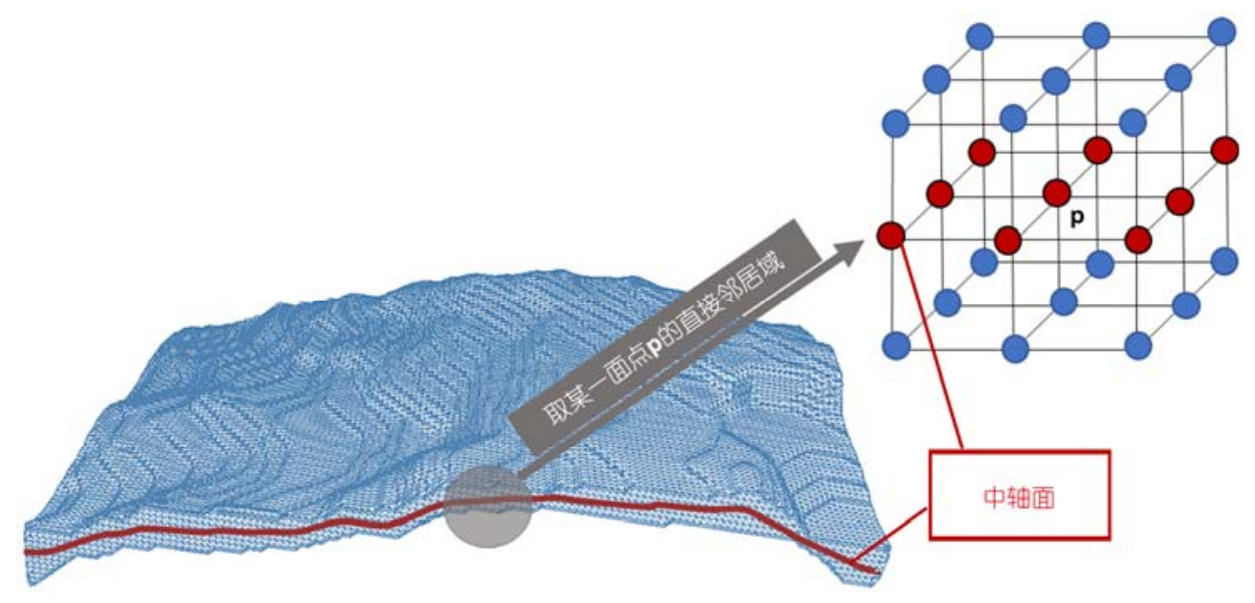

图 5 (网络版彩色)微裂隙空间中轴面及其 $3 \times 3 \times 3$ 单位模板示意图

Figure 5 (Color online) Medial surface of micro-fracture and one of its $3 \times 3 \times 3$ units

处的中轴边缘点作为裂隙空间与孔隙空间的连接点 和分割点, 既是微裂隙骨架面的组成部分, 又包含在 孔隙骨架线中. 提取中轴边缘点可量化微裂隙发育 范围, 即对微裂隙的轮廓进行描述, 同时获取裂隙与 基质孔隙间的连通关系. 由于边缘点必定是中轴面 点的邻居体素, 因此有 $\exists \mathrm{p}=N_{\alpha}(\mathrm{q})$, 其中 $\mathrm{q}$ 为中轴面点, $\mathrm{p}$ 为边缘点, $\alpha$ 代表空间连通性. 特别地, 在边缘点集 中存在部分特殊边缘点, 是骨架线和骨架面的重要 连接点, 也就是包含微裂隙与基质孔隙连通关系的 边缘点, 在边缘点提取过程中标注此类边缘点, 可在 后续孔隙结构特征提取过程中获取孔裂隙连通信息.

将空间维度、图像、邻居域等概念有机地结合起 来, 通过对微裂隙-孔隙空间进行特征点化, 将孔裂 隙空间点分为中轴线点、中轴面点、中轴边缘点与简 单点, 利用拓扑结构权重参数量化各空间点集合的 拓扑结构特征, 基于孔隙空间拓扑学理论分别提取
各点集. 然后结合骨架面与骨架线信息构建“线面共 存”的孔裂隙空间新骨架模型，分别表征孔隙空间与 裂隙空间，真实描述微裂隙-孔隙间的连通关系，简 化微裂隙-孔隙空间模型，进而有效提取孔裂隙空间 的几何-拓扑结构特征.

\section{5 裂隙孔隙空间骨架模型提取方法}

对于本文提出的描述方法对孔隙空间骨架进行 提取, 与传统中轴线提取方法类似, 首先应基于孔隙 空间欧氏距离图的分布确定扫描顺序 ${ }^{[46]}$, 并基于前 文所述的基本邻居域判定规则进行篮选; 当满足面 点条件时, 将其保留; 当判断为边缘点时, 继续保 留, 并进人下一步; 当判断为简单点时, 将其删除, 并在扫描中始终把待扫描点的邻居放人待扫描的队 列中; 完全扫描后得到的包含了面点以及边缘点的 微裂隙空间骨架信息, 详细流程如图6所示.

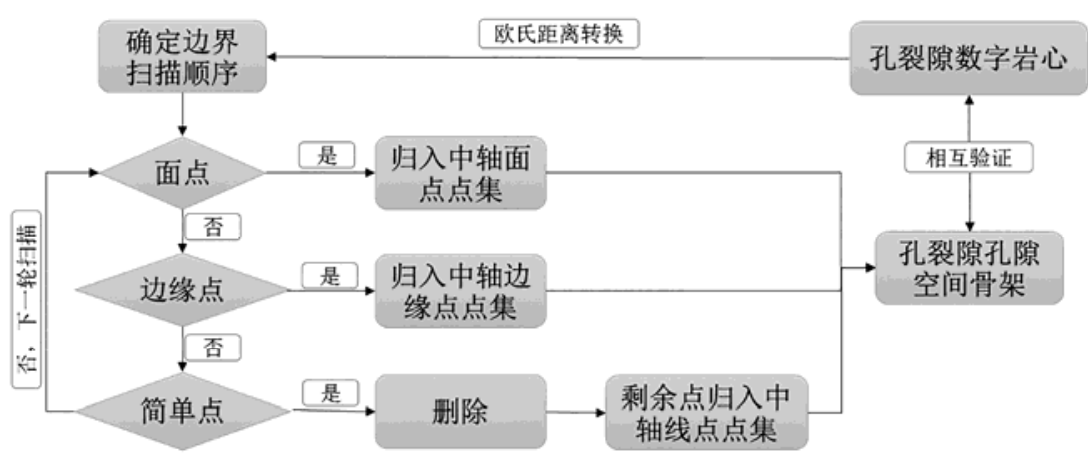

图 6 基于微裂隙拓扑结构特征的骨架提取算法流程图

Figure 6 Algorithm flow chart of new skeleton extraction based on topological characterization of micro-fractured space 


\section{3 裂隙-孔隙空间结构特征提取}

在岩心尺度上, 孔隙半径、微裂隙的开度、倾角 等这些参数已被证明对孔裂隙系统流动性质的改变 有很大作用. 同时, 孔裂隙空间的渗流网络连通性、 孔隙配位数等决定着对油水运移的规律. 基于上述 孔裂隙描述方法可以方便地提取孔裂隙空间的几何 结构特征以及拓扑结构特征, 为后期微观尺度下的 流动模拟打下基础.

\section{1 裂隙-孔隙空间几何结构特征提取}

孔裂隙空间的几何特征是对孔裂隙单元的几何 尺寸和形态分布的描述, 主要包括孔隙的半径、迂曲 度以及微裂隙的孔隙度、开度、倾角等.

(1) 通过最大欧氏距离转换, 计算得到中轴骨架 上的欧氏距离变化, 即孔隙半径及裂隙开度分布.

(2) 迂曲度是多孔介质中有效平均路径长度与 沿渗流方向测量的最短距离之比, 用于描述孔隙流 动路径曲折程度. 迂曲度 $\tau=l_{a} / l_{s}$, 其中 $l_{a}$ 表示连通孔隙 之间的实际长度, $l_{s}$ 表示连通孔隙之间的最短长度. 在骨架模型中, 可以很方便地计算得到两点间的有 效路径及其长度.

(3) 统计裂隙体发育范围内的体素数等方式能 够得到微裂隙体积及其孔隙度.

(4) 通过对中轴面上点的统计与计算可定位微 裂隙体. 例如, 任选裂隙特征区域内一点开始, 遍历 该裂隙的所有体素点坐标, 做算术平均后可得到该 整裂隙的几何中心. 即假设所有缝洞点的坐标记为: $p_{n}(x, y, z)$, 那么该缝洞的中心坐标则为

$$
\left(\frac{\sum_{i=0}^{n} x_{i}}{n}, \frac{\sum_{i=0}^{n} y_{i}}{n}, \frac{\sum_{i=0}^{n} z_{i}}{n}\right) \text {. }
$$

(5) 微裂隙体折角. 岩石中的微裂隙相互连通会 形成微裂隙网络, 若仅靠连通关系将其看作一个整 体裂隙来进行识别、描述, 会对裂隙性质, 特别是流 动性质带来很大的影响. 由于微裂隙交界处通常存 在较大折角, 因此可以细致识别裂隙折角区域, 设定 合适的阈值, 从而区分微裂隙网络. 通过递进式扫描 骨架面模型, 可以统计出裂隙的折角数量和角度, 从 而对裂隙网络进行优化, 开展裂隙结构分析研究.

(6) 微裂隙体相对倾角. 进行折角处理后, 中轴 面的形状可以看作一个较为规则的平面, 因此可以 基于平面几何学的相关知识与前面已经介绍过的微
裂隙中轴面判定相关原理来计算一个微裂隙体对于 某数字岩心平面的相对倾角. 如图7所示, 假设平面 $A B C$ 代表裂缝的中轴面, 此平面的法向量为 $\boldsymbol{n}$, 则基 于解析几何学的相关理论得到平面 $A B C$ 与平面 $X O Z$ 的夹角 $\gamma$ 为

$$
\gamma=180^{\circ}-\arccos \frac{\boldsymbol{n} \boldsymbol{y}}{|\boldsymbol{n}||\boldsymbol{y}|},
$$

其中 $\boldsymbol{y}=(0,1,0)$ 是 $X Z$ 面的法向量. 同理可以得到裂缝 中轴面与另外两个坐标平面的夹角, 即裂缝与数字 岩心某坐标平面的相对倾角可以一一求出.

\section{2 裂隙-孔隙空间拓扑结构特征提取}

孔裂隙空间的拓扑结构特征用来描述孔裂隙之 间相互连接的关系，表征孔裂隙空间连通性，其评价 参数主要包括孔裂隙配位数、裂隙发育范围等.

(1) 孔裂隙配位数是指与微裂隙相互连通的孔 隙个数, 用来表征裂隙与孔隙之间的相互配置关系, 可表征整个孔裂隙空间连通能力. 获取孔裂隙空间 骨架后, 统计连接中轴面与中轴线的边缘点个数可 计算得到微裂隙配位数; 统计中轴线交叉点个数, 可 以计算得到孔隙配位数.

(2) 裂隙发育范围. 一个不规则物体的轮廓由两 部分组成, 即平面的轮廓部分以及垂直于该平面轮 廓的部分, 微裂隙体也不例外. 通过对本文描述方法 中提出的中轴面上的点到其相应固体颗粒边界的距 离进行遍历和排序，可以方便地确定裂隙空间的发 育范围. 对于任一微裂隙体内的点 $\mathrm{p}_{i}$ 来说, 若其所在 的孔隙空间表示为 $P$, 固体颗粒所代表的背景空间

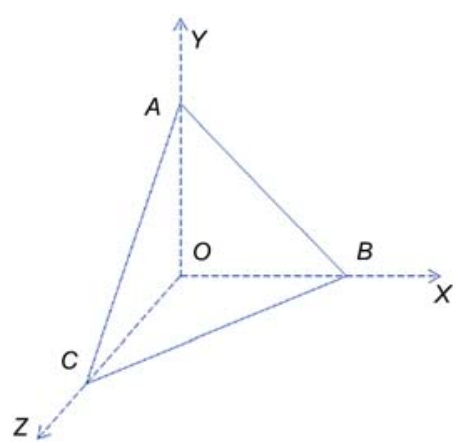

图 7 (网络版彩色)微裂缝相对倾角的计算方法, 其中, $O$ 点为坐标原 点, $X, Y, Z$ 为坐标轴, 平面 $A B C$ 代表裂缝中轴面

Figure 7 (Color online) Calculation of inclination angle of microfractures, point $O$ : origin of coordinates; $X, Y, Z$ are coordinate axises; surface $A B C$ represent the medial surface of micro-fractures 
表示为 $R$, 其到固体颗粒边界的最短欧氏距离可以表 示为

$$
\lambda\left(\mathrm{p}_{i}\right)=\operatorname{Min}\left\{d\left(\mathrm{p}_{i}, r\right): r \in R\right\} .
$$

通过欧氏距离计算公式可以求得该点对应的裂 缝轮廓上的点的坐标, 同时还可以求取次最大值点 的坐标, 计算的越多, 得到的裂隙轮廓就越准确.

\section{4 讨论}

\section{1 理想孔裂隙空间骨架提取}

将上述提取方法用于一些理想的裂隙空间, 如 图8所示的正交十字、理想曲面和圆环空间. 从提取 后的空间骨架结果来看, 不仅保留了它们的面状特 征, 且其空间展布和拓扑结构都与原空间图像保持 一致, 说明本文提出的方法在保留对具有面状特征 的空间的骨架提取方面确实是有效的. 同时, 对图 8 中圆柱体这类呈现完全封闭形态的类孔隙空间的骨 架应用本文方法进行提取时, 提取后的骨架与普通
孔隙空间提取的完全一致，因此本文提出新算法对 普通孔隙空间的拓扑结构没有任何影响.

\section{2 真实孔裂隙空间骨架提取}

图9(a)为来源于碳酸盐岩储层的微裂隙数字岩 心图像，其数据规模为 $150 \times 150 \times 150$ 体素，分辨率 $1.13 \mu \mathrm{m}$, 图像中可见明显的微裂隙构造, 且微裂隙 边缘与其周围分布的微孔隙相连通. 对其进行二值 化等图像处理后，经过本文方法对其进行骨架提取 并计算得到了相应的微裂隙结构表征参数. 如图9(c) 所示为应用本文方法提取得到的图像; 其中包含了 上文提到的简单点点集、中轴面点点集以及边缘点点 集, 与传统方法提取得到的图像相比(图 10), 更接近 微裂隙原始孔隙结构.

为了更直观展示, 将上例图像旋转放大到如图 9(d) 所示角度, 可观察到模型中中轴面与中轴线共 存, 模型包含部分与外部基质连通的普通孔隙空间骨 架，说明采用本文方法还可保持裂隙与基质间的连通

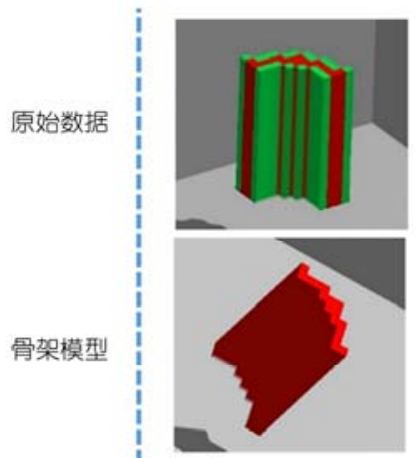

(a)

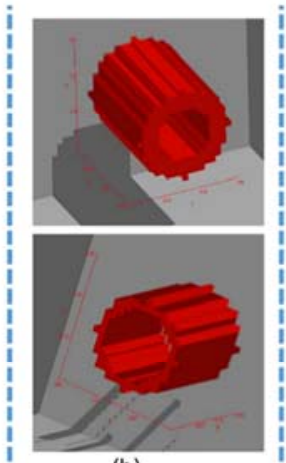

(b)

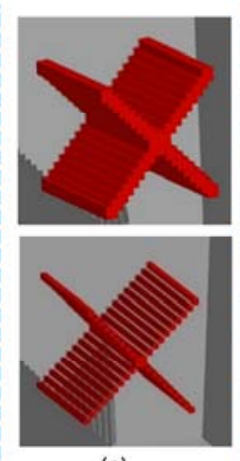

(c)

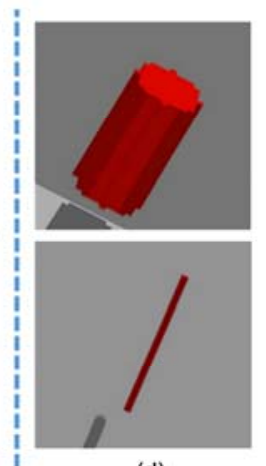

(d)

图 8 (网络版彩色)理想空间结构的骨架提取. (a) 规则曲面; (b) 圆环结构; (c) 正交十字类空间; (d) 圆柱体结构

Figure 8 (Color online) Skeleton extraction of ideal structure. (a) Smooth curved structure; (b) vuggy structure; (c) cross structure; (d) cylinder structure

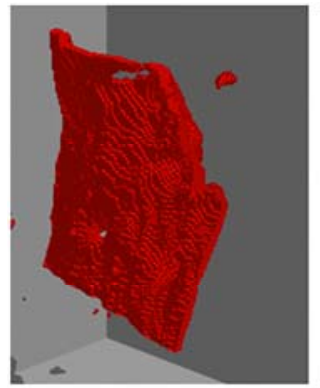

(a)

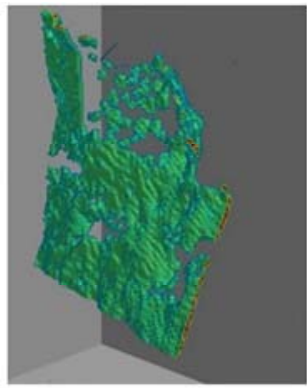

(b)

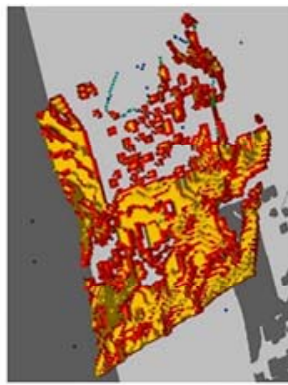

(c)

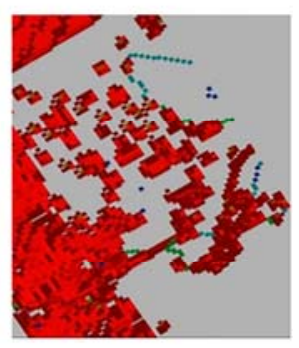

(d)

图 9 (网络版彩色)真实裂隙结构的中轴骨架提取. (a) 原始数据; (b) 欧式测度数据; (c) 中轴骨架面; (d) 骨架模型局部放大图

Figure 9 (Color online) Medial skeleton extraction of real fracture. (a) Raw images; (b) distance map; (c) skeleton model; (d) partial enlargement of skeleton model 


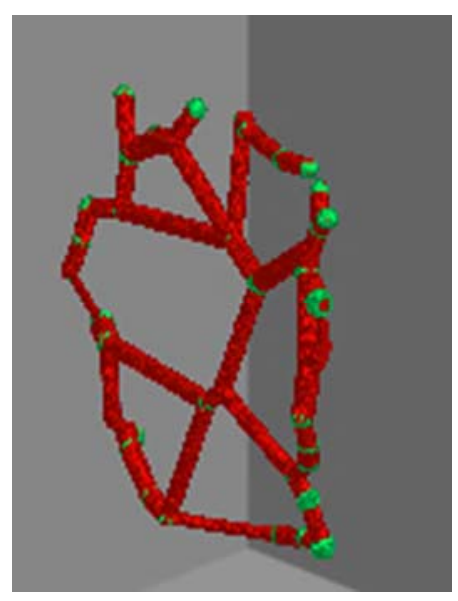

图 10 (网络版彩色)传统中轴线模型骨架

Figure 10 (Color online) Traditional axis skeleton model

性, 这为后期的流动模拟提供了准确的数据基础.

基于对真实孔裂隙空间提取到的中轴骨架模型, 可以进一步计算得到裂隙结构参数, 准确表征孔裂 隙空间结构. 此例中的单裂隙存在一处折角, 裂隙开 度变化位于 $[1,7]$ 体素之间, 平均开度为 2 个体素, 微 裂隙边界坐标为 $(30,40,27) 、(55,63,42)$, 相对 XOZ 面的倾角为 $89^{\circ}$, 相对 $Y O Z$ 平面倾角为 $1^{\circ}$.

\section{5 总结}

微裂隙作为一种特殊的孔隙空间, 是流体在多 孔介质特别是致密介质中渗流的重要通道. 高精度 无损成像技术的快速发展, 为微裂隙-微孔隙空间描
述以及孔裂隙模型构建等研究提供了数据支撑. 本 文基于裂隙空间不同于普通孔隙空间的几何与拓扑 特征, 结合拓扑学相关理论, 得到了含有裂隙与孔隙 数字岩心图像的描述与特征提取方法, 充分考虑三 维裂隙空间区别于普通孔隙的面状特征以及与基质 孔隙之间的相互连通关系, 形成适用于多种孔裂隙 空间的孔裂隙空间描述方法.

(1) 形成了骨架面与骨架线相结合的孔裂隙空 间结构特征描述方法. 提取裂隙骨架面, 保证流体在 裂隙空间的面状渗流特征; 提取孔隙骨架可保证流 体在孔隙空间的管状流动特征; 精细刻画裂隙轮廓 可保证裂隙和基质孔隙无缝真实连接.

(2) 基于空间邻居域与图像连通关系理论等拓扑 学理论, 从裂隙的拓扑结构共性出发, 提出“特征点 化”将孔裂隙空间点进行分类, 结合拓扑结构参数定 义除传统简单点以外的中轴面点、中轴边缘点, 并对 各点集分别识别和提取, 同时形成新的孔隙、裂隙空 间分割方法，保证孔裂隙空间描述的准确性、有效性.

（3）基于新的孔裂隙骨架信息，在拓扑特征描述 方面, 利用空间“距离测度”理论来得到缝洞的轮廓 信息, 真实还原并获取孔裂隙连通关系; 在几何特征 描述方面, 结合宏观上对孔裂隙的描述方法, 将开 度、倾角等几何参数引人微观孔裂隙的描述中, 将几 何参数作为变量对微观缝洞的几何特征进行描述. 新的孔裂隙空间结构特征分析方法将对后续含裂隙 的孔隙空间渗流模拟提供准确数据基础.

\section{参考文献}

1 Karpyn Z T, Piri M. Prediction of fluid occupancy in fractures using network modeling and X-ray microtomography. I: Data conditioning and model description. Phys Rev E, 2007, 76: 016315

2 Yao J, Sun H, Huang Z Q, et al. Key mechanics problems of unconventional shale gas reservoirs (in Chinese). Sci Sin-Phys Mech Astron, 2013, 43: 1527-1547 [姚军, 孙海, 黄朝琴, 等. 页岩气藏开发中的关键力学问题. 中国科学: 物理学 力学 天文学, 2013, 43: 1527-1547]

3 Knackstedt M, Arns C, Ghous A, et al. 3D imaging and flow characterization of the pore space of carbonate core samples. In: Proceedings of International Symposium of the Society of Core Analysts. Trondheim, 2006

4 Madadi M, Sahimi M. Lattice Boltzmann simulation of fluid flow in fracture networks with rough, self-affine surfaces. Phys Rev E, 2003, 67: 026309

5 Prodanovic M, Bryant S L, Karpyn Z T. Investigating matrix/fracture transfer via a level set method for drainage and imbibition. SPE J, 2010, 15: 125-136

6 Yao J, Zhao J L, Zhang M, et al. Microscale shale gas flow simulation based on lattice Boltzmann method (in Chinese). Acta Petrol Sin, 2015, 36: 1280-1289 [姚军, 赵建林, 张敏, 等. 基于格子 Boltzmann 方法的页岩气微观流动模拟. 石油学报, 2015, 36: 1280-1289] 
7 Hughes R G, Blunt M J. Network modeling of multiphase flow in fractures. Adv Water Resour, 2001, 24: 409-421

8 Piri M, Karpyn Z T. Prediction of fluid occupancy in fractures using network modeling and X-ray microtomography. II: Results. Phys Rev E, 2007, 76: 016316

9 Kranz R L. Microcracks in rocks: A review. Tectonophysics, 1983, 100: 449-480

10 Cnudde V, Boone M N. High-resolution X-ray computed tomography in geosciences: A review of the current technology and applications. Earth-Sci Rev, 2013, 123: 1-17

11 Wang L, Jin Y O, Butler I. Interpretation of particle breakage under compression using X-ray computed tomography and digital image correlation. Proced Eng, 2015, 102: 240-248

12 Lee T C, Kashyap R L, Chu C N. Building skeleton models via 3-D medial surface axis thinning algorithms. Graph Model Im Proc, 1994, 56: $462-478$

13 Lindquist W B, Venkatarangan A. Investigating 3D geometry of porous media from high resolution images. Phys Chem Earth A, 1999 24: 593-599

14 Lindquist W B, Venkatarangan A, Dunsmuir J, et al. Pore and throat size distributions measured from synchrotron X-ray tomographic images of Fontainebleau sandstones. J Geophys Res Solid Earth, 2000, 105: 21509-21527

15 Jiang Z. Quantitative characterisation of the geometry and topology of pore space in 3D rock images. Dissertation for Dcotoral Degree. Edinburgh: Heriot-Watt University, 2008

16 Dhanalakshmi N, Latha Y M, Damodaram A. Skeletonization of Players in Dynamic Backgrounds Using Discrete Curve Evolution. New Delhi: Springer, 2016. 689-696

17 Lee J, Son H, Kim C, et al. Skeleton-based 3D reconstruction of as-built pipelines from laser-scan data. Autom Constr, 2013, 35: 199-207

18 Delerue J F, Perrier E. DXSoil, a library for 3D image analysis in soil science. Comput Geosci, 2002, 28: 1041-1050

19 Sok R M, Knackstedt M A, Sheppard A P, et al. Direct and stochastic generation of network models from tomographic images: Effect of topology on residual saturations. Transport Porous Med, 2002, 46: 345-371

20 Blunt M J. Flow in porous media-pore-network models and multiphase flow. Curr Opin Colloid Interface Sci, 2001, 6: 197-207

21 Lopez X, Valvatne P H, Blunt M J. Predictive network modeling of single-phase non-Newtonian flow in porous media. J Colloid Interface Sci, 2003, 264: 256-265

22 Blunt M J, Bijeljic B, Dong H, et al. Pore-scale imaging and modelling. Adv Water Resour, 2013, 51: 197-216

23 Dong H, Blunt M J. Pore-network extraction from micro-computerized-tomography images. Phys Rev E, 2009, 80: 036307

24 Bultreys T, De Boever W, Cnudde V. Imaging and image-based fluid transport modeling at the pore scale in geological materials: A practical introduction to the current state-of-the-art. Earth Sci Rev, 2016, 155: 93-128

25 Wang W, Shahvali M, Su Y. A semi-analytical fractal model for production from tight oil reservoirs with hydraulically fractured horizontal wells. Fuel, 2015, 158: 612-618

26 Wang W, Su Y, Sheng G, et al. A mathematical model considering complex fractures and fractal flow for pressure transient analysis of fractured horizontal wells in unconventional reservoirs. J Nat Gas Sci Eng, 2015, 23: 139-147

27 Riasi M S, Palakurthi N K, Montemagno C, et al. A feasibility study of the pore topology method (PTM), a medial surface-based approach to multi-phase flow simulation in porous media. Transport Porous Med, 2016, 115: 519-539

28 Jiang Z, Wu K, Couples G, et al. Efficient extraction of networks from three-dimensional porous media. Water Resour Res, 2007, 43: 2578-2584

29 Corbett P, Hayashi F Y, Alves M S, et al. Microbial carbonates: A sampling and measurement challenge for petrophysics addressed by capturing the bioarchitectural components. Geol Soc London Spec Publ, 2015, 418: 69-85

30 Wilson J, Chester J, Chester F. Microfracture analysis of fault growth and wear processes, Punchbowl Fault, San Andreas system, California. J Struct Geol, 2003, 25: 1855-1873

31 Morgenthaler D G. Three-Dimensional Simple Points: Serial Erosion, Parallel Thinning, and Skeletonization. Maryland: University of Maryland, 1981

32 Lindquist W B, Lee S M, Coker D A, et al. Medial axis analysis of void structure in three-dimensional tomographic images of porous media. J Geophys Res-Solid Earth, 1996, 101: 8297-8310

33 Han X, Xu C, Prince J L. A topology preserving level set method for geometric deformable models. IEEE Trans Patt Anal Mach Intell, 2003, 25: 755-768

34 Xie W, Thompson R P, Perucchio R. A topology-preserving parallel 3D thinning algorithm for extracting the curve skeleton. Pattern Recogn, 2003, 36: 1529-1544

35 Lohou C, Bertrand G. A 3D 12-subiteration thinning algorithm based on P-simple points. Discrete Appl Math, 2004, 139: 171-195 
Zhou Q Y, Ju T, Hu S M. Topology repair of solid models using skeletons. IEEE Trans Vis Compo Graph, 2007, 13: 675-685

Kong T Y, Rosenfeld A. Digital topology: Introduction and survey. Comput Vis Graph Image Process, 1989, 48: 357-393

Bertrand G, Malandain G. A new characterization of three-dimensional simple points. Pattern Recogn Lett, 1994, 15: 169-175

Borgefors G, Nyström I, Di Baja G S. Computing skeletons in three dimensions. Pattern Recogn, 1999, 32: 1225-1236

Bertrand G. Simple points, topological numbers and geodesic neighborhoods in cubic grids. Pattern Recogn Lett, 1994, 15: 1003-1011

Toriwaki J, Yoshida H. Fundamentals of Three-Dimensional Digital Image Processing. Berlin: Springer, 2009

Palágyi K, Kuba A. A parallel 3D 12-subiteration thinning algorithm. Graph Models Image Process, 1999, 61: 199-221

Ju T, Baker M L, Chiu W. Computing a family of skeletons of volumetric models for shape description. Comput Aided Des, 2007, 39: $352-360$

Palágyi K. A 3D fully parallel surface-thinning algorithm. Theor Comput Sci, 2008, 406: 119-135

Hadwiger H, Hadwiger H. Vorlesungen über Inhalt, Oberfläche Und Isoperimetrie. Berlin: Springer, 1957

Wang X, Yao J, Jiang Z Y, et al. A new method of fast distance transform 3D image based on "neighborhood between voxels in space" theory (in Chinese). Chin Sci Bull, 2017, 62: 1662-1669 [王金金, 姚军, 蒋泽云, 等. 一种新的三维欧式距离变换方法及在数字岩心 中的应用. 科学通报, 2017, 62: 1662-1669] 


\title{
Extraction and identification methods of micro-fractured characteristics information in pore space of porous media based on morphological theory
}

\author{
Xin Wang ${ }^{1}$, Zeyun Jiang ${ }^{2}$, Jun Yao ${ }^{3 *}$, Qi Zhang ${ }^{1}$, Guohao Zhang ${ }^{4}$, Zhen Zhang ${ }^{5}$ \& Liya Duan ${ }^{1}$ \\ ${ }^{1}$ Institute of Oceanographic Instrmentation, Qilu University of Technology (Shandong Academy of Sciences), Qingdao 266000, China; \\ ${ }^{2}$ Institute of Petroleum Engineering in Heriot-Watt University, Edinburgh, UK EH14 4AS, Scotland; \\ ${ }^{3}$ School of Petroleum Engineering, China University of Petroleum, Qingdao 266580, China; \\ ${ }^{4}$ China National Offshore Oil Corporation (Tianjin Branch), Tianjin 300459, China; \\ ${ }^{5}$ Asialnfo's Technology China Research Center, Beijing 100000, China \\ *Corresponding author, E-mail: yaojunhdpu@126.com
}

Natural micro-fractures in ultra-tight formations, such as shales and coal seams, provide key information about pore structure and continuous channel in it. How to identify the geometrical and topological properties of micro-fractured structure and matrix pore space and the correlation between them are the major contributors which can lead to strong calculation results during the following seepage flow simulation. Through characterizing the pore space included micro-fractures (i.e., connectivity capability of pore space, extension of fracture, etc.), we can therefore describe and develop pore-fracture structure and the suitable models to gain better understanding of the roles of micro-fractures on the drainage of hydrocarbons from matrix pores.

In this work, we proposed a new skeleton model to distinguish fractures from pore space via extraction of surface points set of fracture. In the procedure of points set extraction, we improved the classic "medial axis based" shrink method to "medial surface-based" method for new fracture description through introducing a new set of skeleton points (i.e., surface points and edge points of the fracture), one of which describes its aperture and the other is used for collecting connectivity information and determining the extension ranges of the fracture. The new skeleton model can show more comprehensible forms of the real connected junction instead of the former ideal model, voxel-thickness medial surface extracted can also satisfy demands of the classic skeleton extraction model and preserve the topology of the original pore space included micro-fractures in the meantime. New points set classification method mentioned above is determined by considering the difference of their topological properties. Through calculating and collecting their topological number one by one, we can obtain a new skeleton model formed with medial axis and surface. Among them, the simple points set was composed of values of topological number $T_{6}=T_{26}=1$ in the $3 \times 3 \times 3$ direct neighborhood system as before and would be deleted in the process of shrinking pore space in the certain order of the distance values of the space. The surface points forming medial surface was composed of the points close to the center of the micro-fractures in all directions. An object point was defined as surface point if no background voxels continuously existed between any two neighbor voxel that shares a "face" in its $3 \times 3 \times 3$ neighborhood system, which means its topological number $T_{6}>1$. Edge points represented as the junction between fractures and matrix if they are always the one of the 26 neighbors of surface points. Moreover, in the process of obtaining new skeleton model, characteristic parameters and connectivity of micro-fractures can then be easily got via statistics and calculation. Through combining Euclidean distance maps and geometric transformation, we can easily calculated the parameters of width, thickness, orientation, and inclination angle of micro-fractures. Connectivity location information from edge points would play the part of following simulation of flow interaction between fractures and the matrix. As a contrast, ideal and real fracture models were used to verify feasibility of our new methods, all results showed good effectiveness and accuracy. The study will lead to more realistic pore space models and help to extend the applicability to a wider range of porous media especially for the study of multi-scale pore space representation.

This work was inspired by challenges in developing a fast and accurate method for micro-scale modeling in micro-fractured porous media, and potentially applicable for flow simulations in the tight porosity samples. Overall, our new methods improved the level of micro-fracture characterization representation of the pore space including fractures for the following flow simulation.

digital core, micro-fracture, skeleton model of pore space, fractured space modeling, morphological operation

doi: 10.1360/N972017-00311 